\title{
高速SRMによるジアシルリン脂質の分析手法の開発と 異性体分析について
}

\author{
Lipid Isomer Analysis on the Development of SRM Based Method \\ for Diacylphospholipids Profiling
}

\begin{abstract}
山田真希
Masaki YAMADA

株式会社島津製作所分析計測事業部グローバルアプリケーション開発センター Global Application Development Center, Analytical \& Measuring Instruments Division, Shimadzu Corporation

Lipids are the molecules in charge of physiological functions such as membrane structure, energy storage or bioactive lipids themselves. Molecular weight of lipid is at most 2000, which is not so larger than that of DNA or proteins. Over 40,000 lipid species are registered in LIPID MAPS (http://www.lipidmaps.org/). It means that dozens of isomeric and isobaric lipid species are condensed in 1 mass unit. Lipidomics is a technology to analyze comprehensive lipid molecules quantitatively using mass spectrometer. Accurate MS such as time of flight or orbital trap type MS coupled with database search is major platform in lipidomics. Recent study using accurate MS based comprehensive lipidomics shown that over 1000 lipids were identified in biological sample. Widely targeted lipidomics using selected reaction monitoring (SRM) with triple quadrupole MS (TQ-MS) is the other platform. Ultra-fast TQ-MS enables to set 500 SRM transition per second including polarity switching. Here we present that development of SRM based lipidomics methods for phospholipids using TQ-MS coupled with reversed phase chromatography. Over 200 phospholipids were identified using the SRM based method from the lipid extracts of mouse tissues. Also we would like to discuss how to identify lipid isomers and isobaric species in the SRM based lipidomics focused on diacylphospholipids analysis.
\end{abstract}

(Received July 20, 2018; Accepted August 24, 2018)

\section{1.はじめに}

脂質は, 細胞膜構成, エネルギー貯蔵，あるいはそれ自 体が生理活性脂質として働くなど, さまざまな生理機能を 担う生体分子である. 脂質の分子量は, 大きいもので 2000 程度である。核酸やタンパク質ほど大きくないが, LIPID MAPS (http://www.lipidmaps.org/) には4万種以上 の脂質分子が登録されている。これは, 分子量「1」とい う範囲内に, 数十種の異性体と isobaric成分（整数質量が 同じで組成式が異なる成分）が含まれることを意味する。 本稿で取り上げるジアシルリン脂質は, グリセロールに 2 種の脂肪酸がアシル結合したものであり，1．脂肪酸の 組み合わせ異性体，2．二重結合の位置異性体，3．シス・

Correspondence to: Masaki Yamada, Global Application Development Center, Analytical \& Measuring Instruments Division, Shimadzu Corporation, Nishinokyo, Kuwabara-cho 1, Nakagyo-ku, Kyoto 604-8511, JAPAN, e-mail: yamada@shimadzu.co.jp

山田真希, 株式会社島津製作所分析計測事業部グローバルアプ リケーション開発センター, $\bar{\top} 604-8511$ 京都府京都市中京区 西ノ京桑原町 1
トランス異性体, 4. 光学異性体など, さまざまな異性体 がある.

このような異性体を含む多様な脂質分子の分析および包 括的な研究を、リピドミクスと言う。近年の質量分析計の 高速化と高感度化拉よびさまざまなフラグメンテーション 技術開発が，この分野の発展を牽引してきた。リピドミク スにおいては, Quadrupole time-of-flight (Q-TOF) 型や Orbital trap型のような高精度質量分析計が主に利用され ている ${ }^{1)}$ ．高精度MSは，isobaric成分の同定には有効であ るが，組成式が同じ異性体の同定にはMS/MSによるフラ グメンテーションが必須である. Data dependent analysis （DDA）は，ある強度以上のイオンについてMS/MSを行 い, プロダクトイオンスペクトルを取得するシステムであ り, 網羅性という点で優れている ${ }^{2)}$. 一方, 三連四重極型 質量分析計（TQ-MS）によるワイドターゲットリピドミ クスと呼ばれる手法が報告されている3), 4) 近年の TQ-MSの高速化により, 毎秒500以上の selected reaction monitoring（SRM）を，極性切り替えを含めて設定できる ようになった。ワイドターゲットリピドミクスは, 網羅性 
という点では高精度MS システムに劣る。しかし, SRM は, 感度の高さとダイナミックレンジの広さから, 高精度 MS システムでは検出できないような低濃度の脂質成分を 同定・定量できると期待される.

筆者らは，逆相クロマトグラフィーと TQ-MSによる高 速SRMを用いたワイドターゲットリピドミクスの手法を 開発した ${ }^{5)}$ 。この手法により，200以上のリン脂質成分を 生体試料から検出した ${ }^{6)}$. 本稿では, ジアシルリン脂質に 焦点を絞り, リピドミクス分析法の開発において課題であ る異性体分析と isobaric 成分の分離について解説する。高 速SRMによるワイドターゲットリピドミクスがどの程度 の脂質異性体を分析できるのかを実例を交えて紹介し，高 精度MSによるリピドミクス手法と比較してどのような利 点があるのかも解説する.

\section{2. ジアシルリン脂質の構造と質量分析}

\section{1 ジアシルリン脂質の構造}

ジアシルリン脂質 PC $18: 0-18: 2 （ 9 Z, 12 Z)$ の構造を 図 1 に示した。sn-1位にステアリン酸（C $18: 0$, 脂肪酸の 炭素数：二重結合の数), $s n-2$ 位にリノール酸 $(\mathrm{C} 18: 2)$ がアシル結合し，sn-3にフォスファチジルコリン（極性 基）が結合している.このように，グリセロールの $s n-1$ と sn-2に両方に脂肪酸がアシル結合し，リン酸を含む極 性基が結合したものをジアシルリン脂質という。脂肪酸と グリセロールとの結合はアシル結合だけでなく，アルキル 結合とアルケニル結合がある．LIPID MAPSの表記法に従 うと, 脂肪酸表記の頭に $o$-あるいはp-をつける（図 1 -。 アルキルアシル型，アルケニルアシル型のリン脂質とも言 う。結合様式にかかわらず，グリセロールに脂肪酸が結合 したリン脂質を総称して，グリセロリン脂質という.

脂肪酸の二重結合の位置は, カルボニル炭素から数えた 炭素原子の順番で表記する。あるいは, EPA P DHA は $\omega 3$ 脂肪酸と言われるように， $\omega$ とメチル末端から数えた炭素 原子の順番で示す。二重結合のシス体を $Z$, トランス体を Eで表記する。

ジアシルリン脂質には, 脂肪酸の組み合わせ異性体 composition isomerがある. フォスファチジルコリン PC $36: 2$ (脂肪酸の総炭素数: 脂肪酸の二重結合の総数) で
は, 図 1 で示したPC $18: 0$ (ステアリン酸) $/ 18: 2$ (リノー ル酸）という組み合わせだけでなく，PC 18:1/18:1（才 レイン酸), PC $16: 0$ (パルチミン酸)/20:2, PC $14: 0$ (ミリスチン酸) $/ 22: 2$, といったように, 複数の組み合わ せが考えられる。これらはすべて同じ組成式 $\mathrm{C}_{44} \mathrm{H}_{84} \mathrm{NO}_{8} \mathrm{P}$, 同じ分子量785.5935（monoisotopic mass）である. LIPID MAPSでは, PC $36: 2$ につて 14 種の脂肪酸が考慮され ており，二重結合の位置異性体，シス・トランス異性体， およびsn-1とsn-2が入れ替わった reverse isomerを含めて, 40 種の異性体が登録されている。

\subsection{MS/MSによるジアシルリン脂質のフラグメンテー} ション

ジアシルリン脂質はその極性基により，フォスファチジ ルコリン (PC), フォスファチジルエタノールアミン (PE), フォスファチジルイノシトール (PI), フォスファ チジルグリセロール（PG），フォスファチジルセリン (PS)，フォスファチジン酸（PA）に分類される. MS/MS により検出される極性基のプロダクトイオンを図 2 に示し た．極性基の脱離によるイオンは，PI以外についてはポ ジティブモードで検出される。図には示さなかったが, PSについてはネガティブモードで 87 のニュートラルロス を生じる7). PC, PIに関してはプリカーサーイオンス キャンで，PE，PG，PSについてはニュートラルロスス キャンで網羅的にリン脂質成分を分析することができる. 例えば，ポジティブイオンモードで検出されるプロダクト イオン $m / z 184.1$ に対するプリカーサーイオンスキャンに より， $m / z 786.6$ にイオンが検出されれば，その成分は PC $36: 2$ であると推測される。ささに，ネガティブイオン モードで脂肪酸のプロダクトイオンが検出できれば，脂肪 酸の組み合わせが同定できる。したがって，極性切り替え はジアシルリン脂質の定性に極めて有効である．Brown ら は，プリカーサーイオンスキャンとニュートラルロスス キャンによるリピドミクス解析により，グリセロリン脂質 97 成分の組み合わせ異性体を同定した ${ }^{8)}$.

ここで，isobaricな成分の分析について説明するため, 図1のPC $36: 2$ を再度取り上げたい. LIPID MAPSには PC $36: 2$ に対するisobaricなリン脂質として, PE $40: 9$; $\mathrm{C}_{45} \mathrm{H}_{72} \mathrm{NO}_{8} \mathrm{P}$, monoisotopic mass 785.4996, PS $36: 3$;

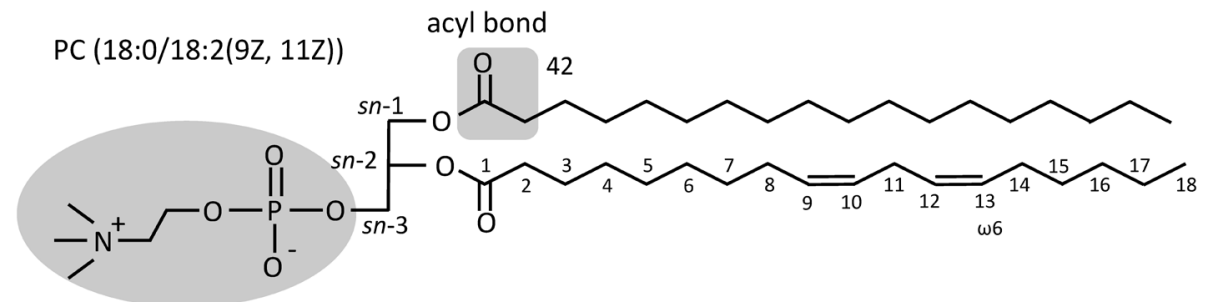

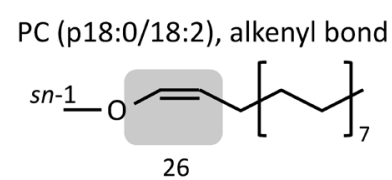

PC (018:0/18:2), alkyl bond

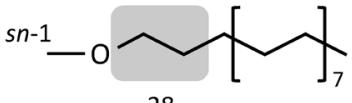

図1.PC 18:0/18:2, 1-octadecanoyl-2-(9Z,12Z-octadecadienoyl)-sn-glycero-3-phosphocholineの構造. アルケニルタイプとアルキル タイプの結合様式を下に示した。アシル，アルケニル，アルキル部位の質量を付記した。 

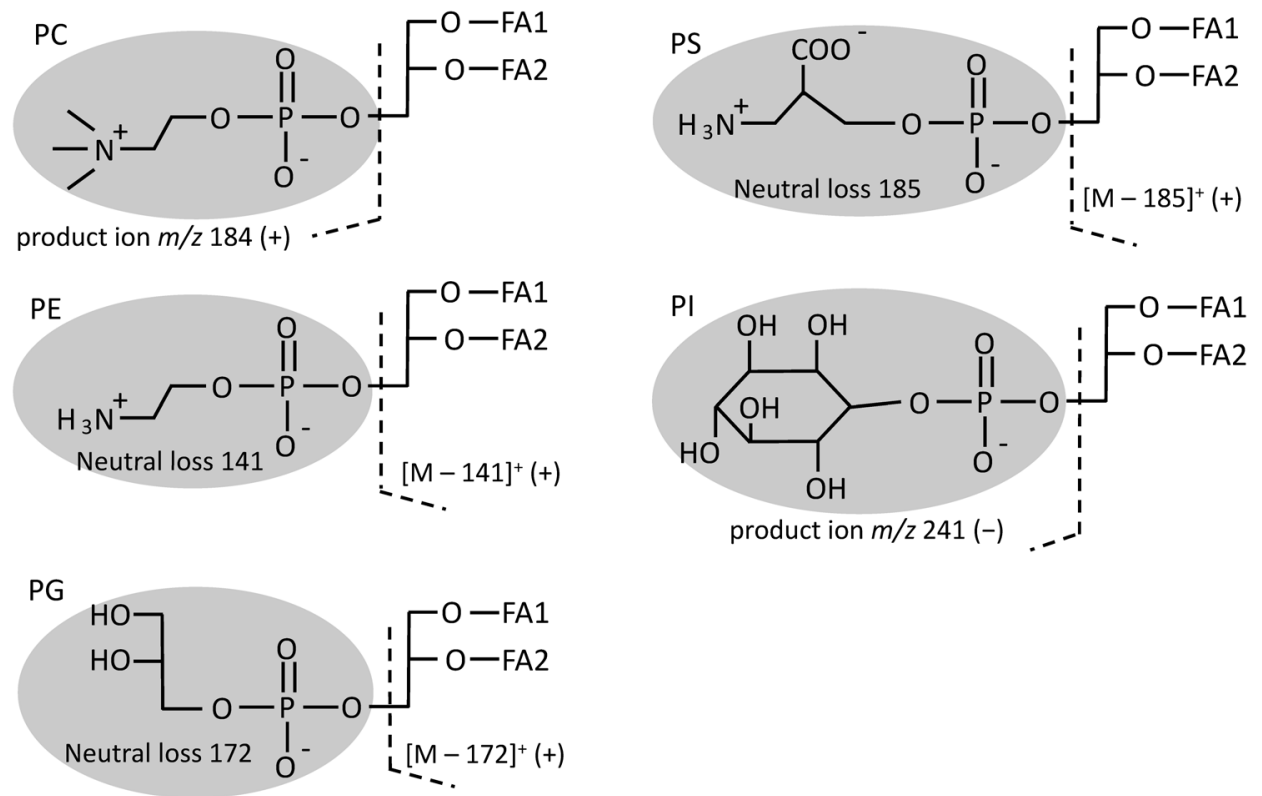

図2.リン脂質のポーラーヘッド構造と，プロダクトイオン．FA1 と FA2 は脂肪酸を示す。（+）はポジティブモード，（一）はネガ ティブイオンモードを示す.

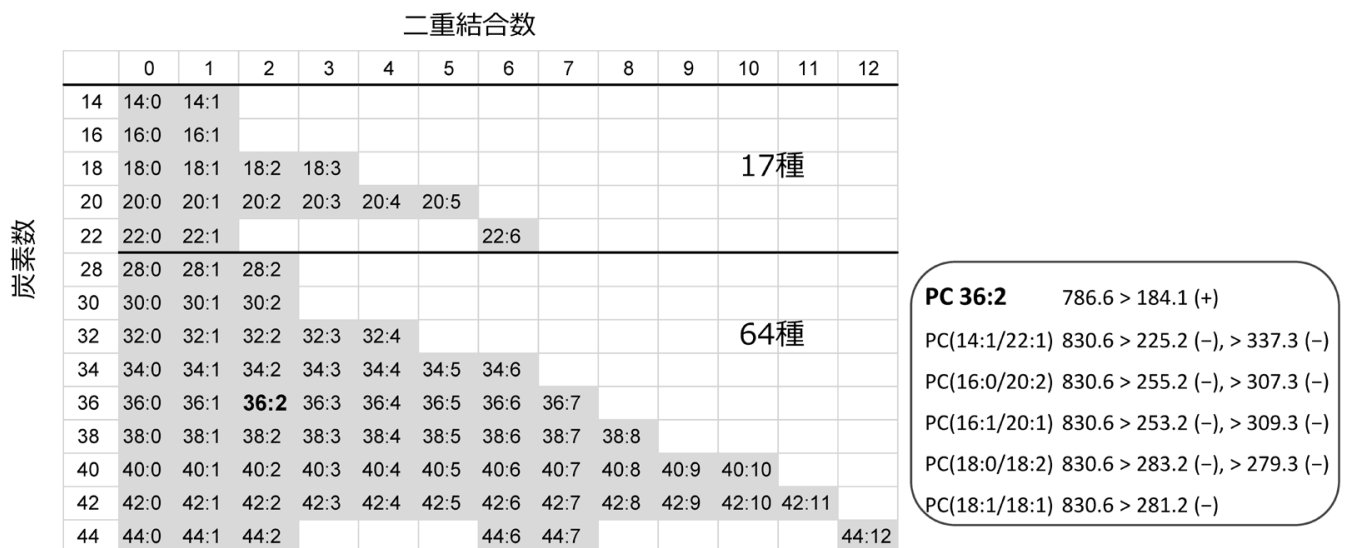

図3. 考慮した脂肪酸 17 種と, ジアシルリン脂質の 64 種. 右には, PC $36: 2$ のつの脂肪酸の組み合わせと, 組み合わせを同定す るために必要な 9 個のSRMを示した。 ポジティブモード（+）のプリカーサーイオン $m / z \quad 786.6$ はプロトン付加体. ネガティ ブモード (一) のプリカーサーイオン $m / z 830.6$ はギ酸アダクト.

$\mathrm{C}_{42} \mathrm{H}_{76} \mathrm{NO}_{10} \mathrm{P}$, monoisotopic mass 785.5207, などが登録さ れている. 質量分解能が 5 万を越えるような高精度質量分 析計であればこれらのプリカーサーイオンを分離すること ができる. 分解能が低い三連四重極型質量分析計でも, 上 記3種の isobaricな分子種は極性基が異なるため, 極性基 のプロダクトイオンを検出することで判別できる．脂肪酸 の組み合わせを同定するためには上述のとおり脂肪酸由来 のプロダクトイオンを検出する必要があり，これは高精度 質量分析計でも三連四重極型でも同じである。極性基が同 じでも isobaricなリン脂質は生じる.アシル基とアルケニ ル基の質量差16あるいはアルキル基との差14を二重結合 の数で相殺されるパターンがあり, 例えば, PC $36: 7$; $\mathrm{C}_{44} \mathrm{H}_{74} \mathrm{NO}_{8} \mathrm{P}$, monoisotopic mass 775.5152 と PC o-36:0; $\mathrm{C}_{44} \mathrm{H}_{90} \mathrm{NO}_{7} \mathrm{P}$, monoisotopic mass 775.6455, が挙げられる. このパターンの isobaric成分の同定には, 後述する逆相ク
ロマトグラフィーでの分離が有効である。

\section{3. 高速SRMによるジアシルリン脂質分析法の開発}

\section{1 ジアシルリン脂質の SRM 設定と逆相クロマトグラ フィー}

筆者らは，逆相クロマトグラフィーとリン脂質構造に特 異的なプロダクトイオンをSRMでモニターすることで, ジアシルリン脂質の脂肪酸組み合わせ異性体765成分を分 析できるメソッドを開発した ${ }^{5)}$. まず，極性基について は, PC, PE, PG, PI, PSの5種を考慮することとした. 考慮する脂肪酸は，17種類に絞ることとした（図3）。ジ アシルリン脂質の「総炭素数：総二重結合数」の種類が各 極性基について 64 種となり，計 320 種のSRMを作成した. この 320 種の SRM は, プリカーサーイオンの $m / z$ と極性基 の脱離によるプロダクトイオンの $m / z$ から成る. 次に, 
SRMで脂肪酸の組み合わせを決定するため, 脂肪酸その もののプロダクトイオンの $m / z$ から成る SRMを作成した. 例えば, PC $36: 2$ にいて, 脂肪酸のプロダクトイオンを 含むSRMが9個必要となる（図3）。765成分に対して 1445 個のSRMが必要となり, 極性基のプロダクトイオンの SRM（320個）と合わせ, 計1765個のSRMを作成した。 使用したTQ-MS（LCMS-8060, 島津製作所）は 5 ミリ秒 で切り替えながらモニターできる。しかし，1765個の SRMを同時にモニターすると, 秒速 500 個の高速SRMで も，ループ時間（1成分についてのプロット間隔）が3秒 以上になる。クロマトグラフィーで得られるピーク幅は, 半值幅で 3 秒程度であるため, ループ時間は 1 秒以内が望 ましい. そこで, 最初に極性基をモニターする 320 個の SRMで 1 度分析し, 検出された成分について脂肪酸の組み 合わせを決定する SRM を融合し，2回目の分析で脂肪酸の 組み合わせを決める手法をとった。 320 個のSRM分析の ループ時間は，極性切り替えを含めて 0.65 秒となる．脂肪 酸決定用のSRMを融合した際にループ時間が 1 秒を越え るような場合は, メソッドを分割して測定することとし た.

逆相系クロマトグラフィー条件について, カラムは Phenomenex社のコアシェルカラム（Kinetex ${ }^{\mathrm{TM}} \mathrm{C} 8$ ）を用 い, 移動相 $\mathrm{A}$ に $20 \mathrm{mM}$ ギ酸アンモニウム水溶液を, 移動 相Bにアセトニトリル：イソプロパノール $=1: 1$ を用い た.「二重結合の数の違い」による分離を良くするため, 直線的なグラジエントではなく，カーブドグラジエントを 用いた. リン脂質が溶出する付近においてできるだけ勾配 を緩やかにすることで, 同じ総炭素数のジアシルリン脂質 について, 二重結合が 1 個増えると溶出時間が 0.5 分から 1分速くなることを確認した（図4).リピドミクスにおい て, 二重結合 1 個違いで生じる同位体の区別は難題であ る.図 4のれ印で示したピークは, PC $38: 6$ と PC $38: 4$ に 対して+2の同位体が, それぞれPC $38: 5$ と PC $38: 3$ の SRMクロマトグラムで検出されていることを示している. PC 38:4の monoisotopic mass は809.6であり，この強度を $100 \%$ としたときの+2の同位体存在比は約 $15 \%$ あ。.図 4 では, PC $38: 4$ の強度が強いため, PC $38: 3$ より PC $38: 4+2$ のピーク強度が大きく検出されており, ピークの

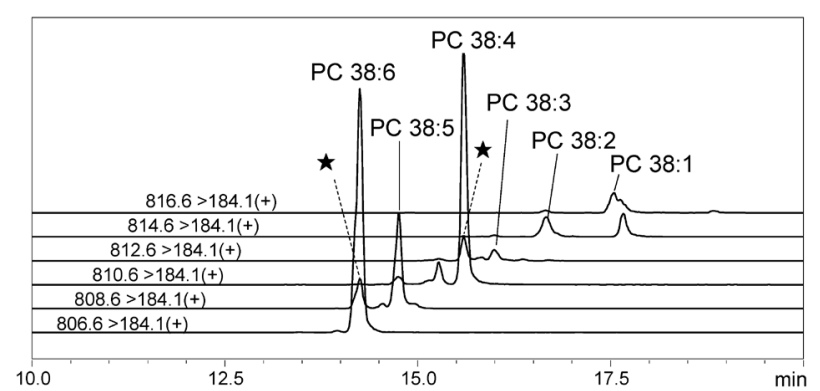

図4. 血清試料のSRMクロマトグラム．PC $38: 1 〜$ PC $38: 6$ について, 極性基のプロダクトイオン $m / z \quad 184.1$ (+) をモニターした。れで示したピークは，二重結合が 1 個多い成分の +2 の同位体が検出されたもの.
帰属を誤る可能性が高い. 脂肪酸のプロダクトイオンを検 出することで, このような䛊同定を減らすことができる. さらに，二重結合差による分離度を良くすることで溶出時 間を予想しやすくなり，ょり確度の高いピーク帰属が可能 となる. 前項で述べたPC $36: 7$ と PC o-36:0 については 5 分程度の保持時間差が生じると予測できる。筆者らは，同 じ総炭素数のリン脂質について，ジアシル型よりアルケニ ル型（p-）の溶出時間のほうが遅いことを確認している.

\section{2 マウス組織のリン脂質プロファイリング}

本手法によりマウスの 4 つの組織（脳，脾臓，肺，肝 臓）におけるリン脂質プロファイリングを行った。まず, 極性基をモニターするSRMで分析し，検出された成分に ついて脂肪酸同定用のSRMを融合したところ，970個の SRMが作成された（スフィンゴミエリン（SM）とリゾリ ン脂質のSRMも含む).ループ時間が1秒を越えたため, メソッドをPCとSMの 407 個のSRMと，PE，PG，PIおよ びPSの563個のSRMの2つに分けて分析した。計188成分 のジアシルリン脂質を検出した。すべて脂肪酸の組み合わ せ異性体を区別して同定しており，その内訳は，PCが 88 種, PEが 63 種, PGが 10 種, PIが 18 種, PSが 9 種であっ た（付属表1).PE 36:5について，各組織で得られた SRMクロマトグラムを図5に示した。PE $16: 1 / 20: 4$ を 13.0 分に, PE $16: 0 / 20: 5$ を13.1分に検出した. 肝蔵組織 の抽出液においては, PE $18: 2 / 18: 3$ が僅かながら検出さ れた. 極性基のニュートラルロスによるプロダクトイオン は両異性体で検出されるため，738.5>597.5（+）のSRM クロマトグラムにおいてはピークが分離しなかったが，脂 肪酸のプロダクトイオンをモニターしたSRMクロマトグラ ムでは，アラキドン酸（20:4）と EPA（20:5）を含むピー クが分離した（図5).PE $16: 0 / 18: 3, \mathrm{PE} 16: 0 / 20: 3, \mathrm{PE}$ $16: 1 / 20: 3$, PE $18: 0 / 20: 3$, PE $18: 1 / 20: 3$ の 5 成分につい ては, 溶出時間の異なる2つのピークをそれぞれに検出し た（付属表1）。これらはsn-1とsn-2が入れ替わった reverse isomerであると考えている．以上のように，極性基 のプロダクトイオンと脂肪酸のプロダクトイオンをほぼ同 時に検出することで，信頼性の高い同定が可能である。ま た，リン脂質に含まれるアラキドン酸やEPAの相対量を 検体間において比較することも可能である.

Gazos-Lopesらは，高精度MS システムにより 1000 以上 の脂質成分を生体試料から検出した ${ }^{9)}$ 。このうちグリセロ リン脂質が 434 成分検出され，ジアシルリン脂質は 294 成 分同定されていた。 isobaricな成分については, PC $18: 1 / 18: 2\left(\mathrm{C}_{44} \mathrm{H}_{82} \mathrm{NO}_{8} \mathrm{P}, 783.5778\right) \quad と \mathrm{PE} p-18: 1 / 22: 1$ $\left(\mathrm{C}_{45} \mathrm{H}_{86} \mathrm{NO}_{7} \mathrm{P} ， 783.6142 ）\right.$ など，極性基が異なるパターン が同定された。このように，網羅性の高さが高精度MS シ ステムのメリットであるが,「脂肪酸組み合わせが決まっ たジアシルリン脂質」に限れば，上記文献では 156 成分が 同定されており，筆者らが高速SRMで同定した成分数 （188成分）より少なかった。これは，極性基のプロダク トイオンだけ検出でき，脂肪酸のプロダクトイオンは検出 できなかったためと考えられる。分析した生体試料が異な 

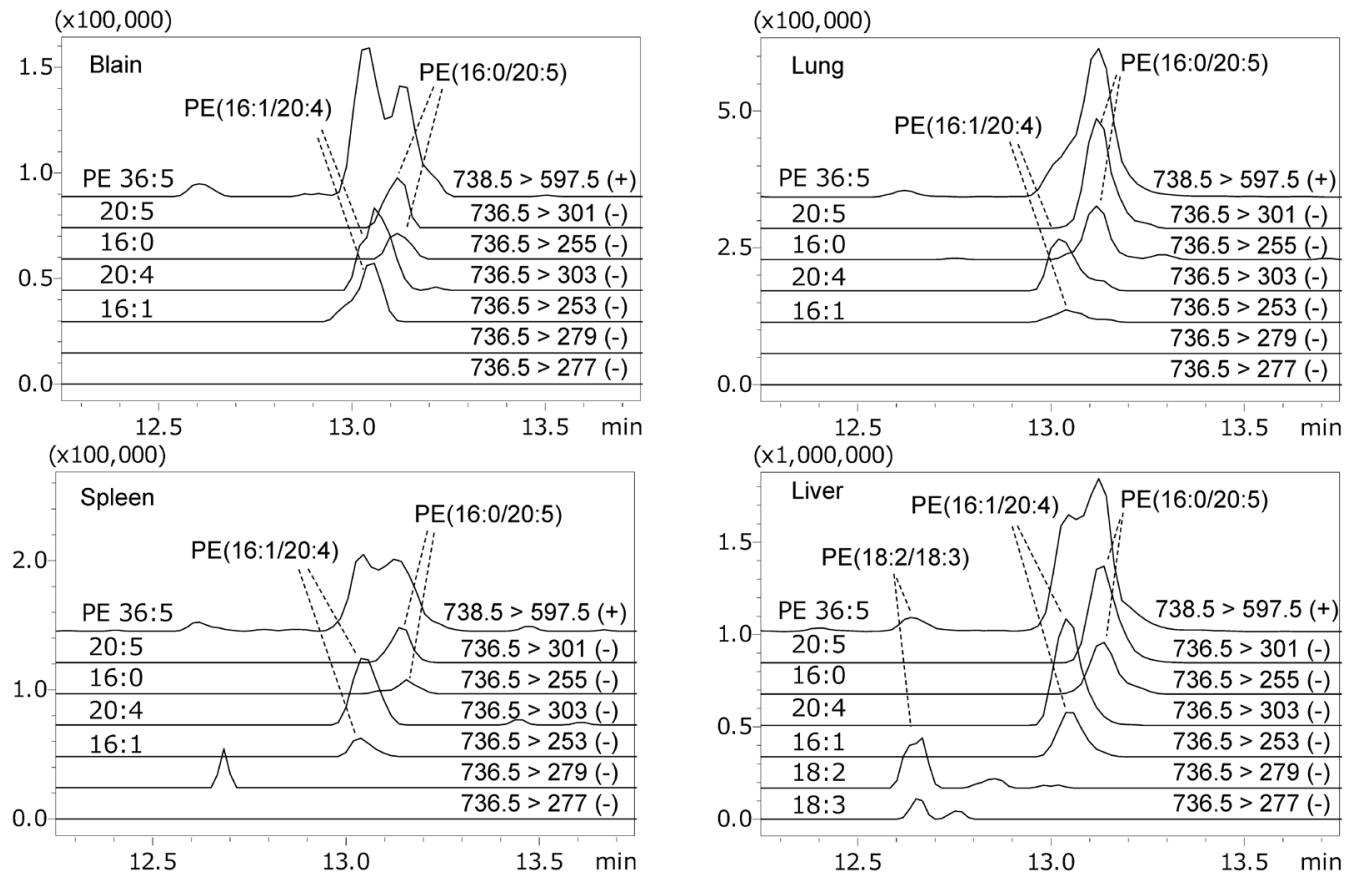

図 5. マウスの組織（脳，脾臟，肺，肝臓）からの脂質抽出液について，PE 36:5の極性基のニュートラルロスによるSRMクロマト グラム > 597.5 (+) と，脂肪酸組み合わせ同定に用いたSRMクロマトグラム>301 (20:5), >255 (16:0), $303(20: 4), 253$ $(16: 1), 279(18: 2), 277(18: 3)$.

るため同定数だけで比較することはできないが, DDAよ りもSRMの方が感度的に有利であり, 低濃度でマイナー な脂肪酸組み合わせ異性体を同定できると考える。

\section{3 リピドミクスにおける二重結合位置の解析}

冒頭で挙げた脂質異性体に対して，上述の高速SRMに よる分析手法で同定できる異性体は, 脂肪酸の組み合わせ の違いによる構造異性体までといえる. Orbital trap型の DDAにおいても, 脂肪酸のプロダクトイオンが検出され ない状況では, C-C結合の切断によるプロダクトイオン は検出されない．脂肪酸のプロダクトイオンが検出されて いる場合でも，二重結合位置の決定に至るほどの感度で検 出できるケースは稀であると推測する.

脂質二重結合位置の同定が可能なフラグメンテーション として, Paternò-Büchi反応 $(\mathrm{PB} 反 \text { 応 })^{10)}$, EIEIO $^{11)}$, オゾ ン分解法 ${ }^{12)}$, などが開発されている. $\mathrm{PB}$ 反応は, 二重結 合位置をアセトンとの反応でラベル化し，CIDによるラベ 儿化部位特異的な開裂を起こす手法である。アセトンとの 反応はオンラインでUV照射することで行える.この手法 により，リン脂質中のオレイン酸の二重結合の 9 位と 11 位 の比を, 正常とがんの組織において網羅的に解析した ${ }^{10)}$. EIEIOは二重結合位置に加え, シス・トランス異性体の区 別にも応用されている ${ }^{11)}$. イオンモビリティーによる二 重結合とシス・トランス異性体の区別は，リピドミクスの スループットを落とさずに情報が得られる点で魅力的であ る ${ }^{12)}$. 高橋らは，水素引き抜き開裂Hydrogen abstraction dissociation（HAD）を開発し，脂肪酸の二重結合位置を 決めた例を報告している ${ }^{13)}$. HAD は，1価のイオンにつ いてフラグメンテーションが行えるため, 脂質分子の解析 に有効である。
このように, 脂質二重結合位置の解析は, リピドミクス の新しい切り口として急展開している.

\section{4. まと め}

本稿では, 高速SRMによるワイドターゲットリピドミ クスにより, 脂質異性体と isobaric成分がどの程度分析で きるのかを, ジアシルリン脂質にフォーカスして解説し た．脂肪酸組み合わせ異性体の同定については，高精度 MS システムと比較して, SRMのほうが深彫りして同定で きることを示した，isobaric成分については，脂質分子で 生じうる2つのパターンを示し，これらはSRMでも分離・ 同定が打拉竘可能であることを示した。 上述のジアシル リン脂質と同じクロマトグラフィー条件で，コレステリル エステルやトリアシルグリセロールを高速SRMでモニ ターする手法を検討した血清あるいは全血から ChEが 11 成分, TAGに関しては26成分について脂肪酸の組み合わ せを同定した ${ }^{14)}$. 今後, ジアシルグリセロールやセラミ ドなど著者が未開発の脂質成分について, ターゲットを拡 大したいと考えている.

LIPID MAPSに登録されているリン脂質の異性体を見て みると，半数以上は二重結合位置とシス・トランス異性体 である. 今後, 二重結合位置解析手法の開発と生体試料の 解析が進み，その生理学的意義が解明されていくだろう.

本稿で垣間見たように，脂質の種類は多様である．生物 はこの多様な脂質分子を巧妙に操り, 生命維持に利用して いる。一方，そのバランスが崩れて脂質異常が生じると， 各種疾患の原因となる。リピドミクスの手法がさらに発展 し, 生命現象を紐解き, 疾患メカニズムの解明や創薬研究 の一助となることを期待する. 
謝＼cjkstart辞＼cjkstart東京大学リピドミクス社会連携講座の徳岡涼美 先生, 北芳博先生より, 高速SRMによるリン脂質の分析 法開発において多くのご助言を賜り，また，マウス組織か らの脂質抽出液をご提供いただきました。この場をお借り しまして御礼申し上げます。

\section{文献}

1) T. Cajka and O. Fiehn, Trends Analyt. Chem., 61, 192 (2015).

2) B. S. Breitkopf, et al., Metabolomics, 13 (3), 30 (2017).

3) H. Tsugawa, et al., Anal. Chem., 85, 5191 (2013).

4) H. Takeda, et al., J. Lipid Res., 59, 1283 (2018).

5) T. Nakanishi, et al., WP-526, 64th Annual Meeting of the American Society for Mass Spectrometry Conference on Mass Spectrometry and Allied Topics (2016).
6) M. Yamada and T. Nakanishi, MP-422, 65th Annual Meeting of the American Society for Mass Spectrometry Conference on Mass Spectrometry and Allied Topics (2017).

7) R. Taguchi, et al., J. Mass Spectrom., 35, 953 (2000).

8) S. H. J. Brown, et al., PLOS ONE, DOI:10.1371/journal. pone.0163972 (2016).

9) F. Gazos-Lopes, et al., PLOS Pathogen, 13(12), e1006800 (2017).

10) X. Ma, et al., PNAS, 113, 2573 (2016).

11) T. Baba, et al., J. Lipid Res., 57, 2015 (2016).

12) B. L. J. Poad, et al., Anal. Chem., 90, 1292 (2018).

13) H. Takahashi, et al., Anal. Chem., 90, 7230 (2018).

14) M. Yamada and T. Nakanishi, ThP-540, 66th Annual Meeting of the American Society for Mass Spectrometry Conference on Mass Spectrometry and Allied Topics (2018).

Keywords: lipidomics, SRM, isomer identification 
付属表1. マウス組織から検出されたジアシルリン脂質とピーク強度（高さ）．ピーク高さはマウス 5 匹のデータの平均值 $(n=5)$. NDは非検出.

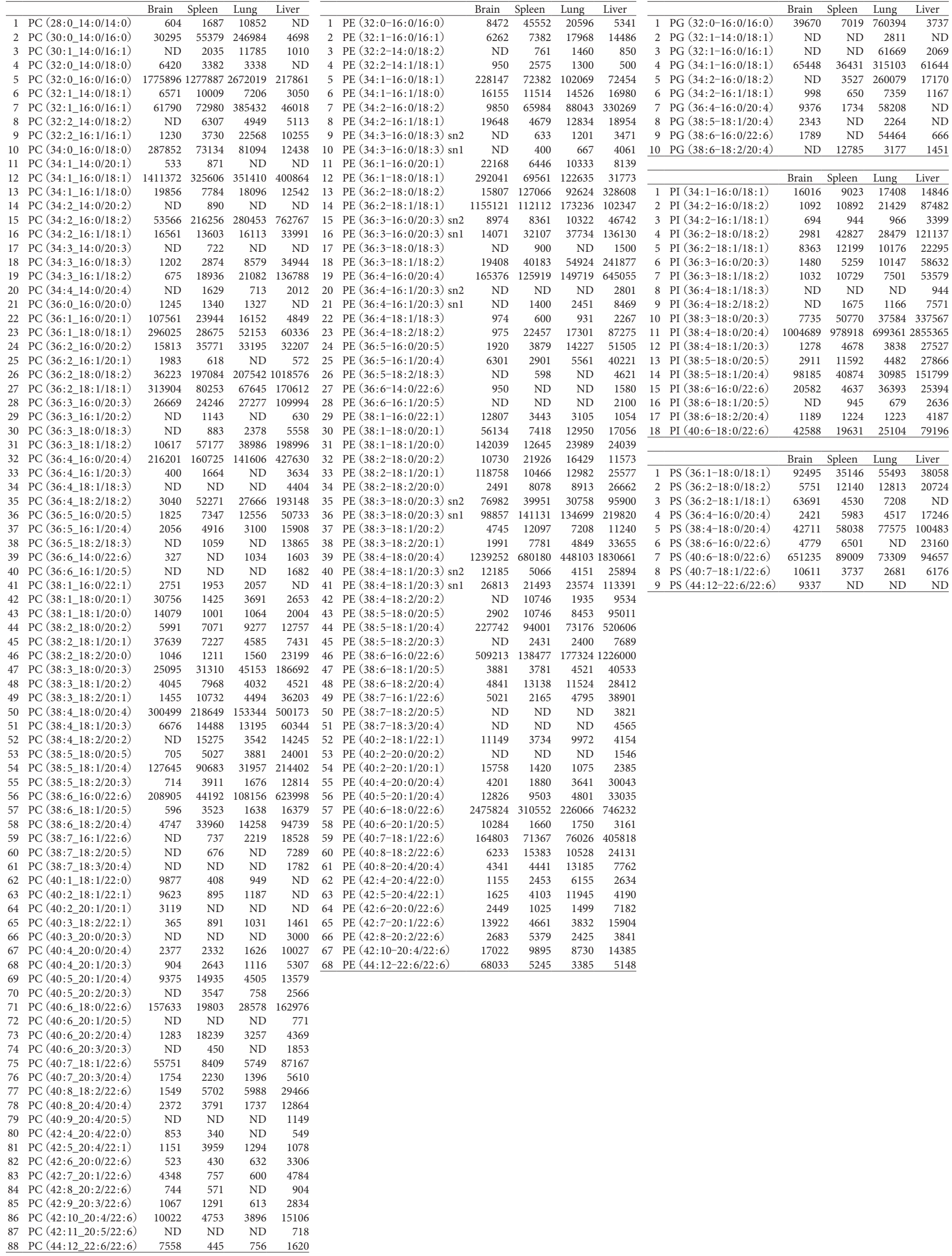

